\title{
The effects of sevoflurane anesthesia on hemodynamics and cerebral artery diameters in endovascular treatment of intracranial aneurysm: A pilot study
}

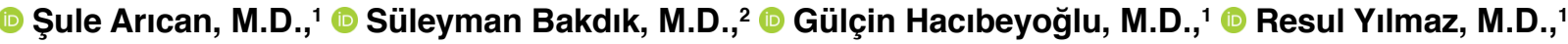

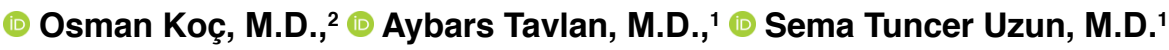

${ }^{1}$ Department of Anaesthesiology and Reanimation, Necmettin Erbakan University Faculty of Medicine, Konya-Turkey

${ }^{2}$ Department of Radiology, Necmettin Erbakan University Faculty of Medicine, Konya-Turkey

\begin{abstract}
BACKGROUND: Cerebral autoregulation is a steady-state of cerebral blood flow despite major changes in arterial blood pressure. Inhalation anesthetics are cerebral vasodilators. In <I MAC values, the net effect is a moderate decrease in cerebral blood flow and maintenance of responsiveness to carbon dioxide. This study aims to investigate the effects of steady-state sevoflurane anesthesia on hemodynamic and cerebral artery diameter measurements in patients undergoing flow diverter device placement under general anesthesia.
\end{abstract}

METHODS: Forty-six patients aged 18-70 years who underwent flow diverter devices under general anesthesia were included in this study. Routine monitoring was performed on the patients. Mean arterial pressure (MAP) values were recorded. Internal carotid artery, middle cerebral artery and anterior cerebral artery diameter measurements were made from digital subtraction angiography (DSA) images of patients with anterior aneurysms. Baseline artery, right posterior cerebral artery and left posterior cerebral artery diameter measurements were made from DSA images of patients with posterior aneurysms. These measurements were recorded as preoperative measurements. The same measurements were made from the DSA images performed before the Flow diverter device placement procedure performed under steady-state sevoflurane anesthesia for the same patients. These measurements were recorded as peroperative measurements.

RESULTS: The average age of the patients was $56.6 \pm 15$. I. The MAP of the patients before induction was $76.28 \pm 5.13 \mathrm{mmHg}, \mathrm{MAP}$ after induction was $64.36 \pm 3.23 \mathrm{mmHg}$, and MAP during sevoflurane anesthesia was $68.26 \pm 4.30 \mathrm{mmHg}$, there was a statistically significant difference. There was a statistically significant difference between the preoperative and perioperative values of anterior cerebral artery diameters. There was a strong relationship between the MAP change percentage and the ICA diameter change percentage $(p<0.001, p=-0.785)$ and a moderate relationship between the MCA diameter change percentage $(p=0.033, p=-0.338)$.

CONCLUSION: In patients undergoing flow diverter devices, <I MAC sevoflurane has a hemodynamic effect and creates significant vasodilation in the cerebral artery diameters.

Keywords: Cerebral artery diameter; flow diverter device; general anesthesia; sevoflurane.

\section{INTRODUCTION}

Cerebral aneurysm occurs when the high blood flow rate expands the artery wall due to the focal weakness of the vessel. [I] Unruptured cerebral aneurysms may manifest clinically by their mass effect on adjacent neurologic structures, or they may be discovered incidentally when a patient has a neuroimaging study for another indication. Pipeline Embolization Device or Flow Re-Direction Endoluminal Device, which is flow diverter for the treatment of cerebral aneurysm, is pop-

Cite this article as: Arıcan Ş, Bakdık S, Hacıbeyoğlu G, Yılmaz R, Koç O, Tavlan A, et al. The effects of sevoflurane anesthesia on hemodynamics and cerebral artery diameters in endovascular treatment of intracranial aneurysm: A pilot study. Ulus Travma Acil Cerrahi Derg 2021;27:200-206.

Address for correspondence: Şule Arıcan, M.D.

Necmettin Erbakan Üniversitesi Tıp Fakültesi, Anesteziyoloji ve Reanimasyon Anabilim Dalı, Konya, Turkey

Tel: +90 332 - 2236000 E-mail: drsulearican@hotmail.com

Ulus Travma Acil Cerrahi Derg 2021;27(2):200-206 DOI: 10.14744/tjtes.202I.00269 Submitted: 28.07.2020 Accepted: 28.12.2020

Copyright 2021 Turkish Association of Trauma and Emergency Surgery 
ular treatment option. Flow diverter devices (FDD) are new generation stents placed in the main artery at the level of the aneurysm neck to disrupt the intra-aneurysmal flow. It progressively creates intra-aneurysm thrombosis and offers good support for the development of the neointima. ${ }^{[2]}$

Placement of FDD can be done safely under conscious sedation. The occlusion rate, functional outcome and complications do not differ between FDD placement with conscious sedation or under general anesthesia. ${ }^{[3]}$ However, most flow diverter procedures are performed under general anesthesia for various reasons, such as general comfort, patient comfort, better control of breathing and hemodynamics, and better visualization as a result of reduced motion artifact in an immobile patient. ${ }^{[4]} \mathrm{A}$ combination of total intravenous anesthesia or a volatile agent with intravenous remifentanil is recommended, which can help maintain rapid induction and patient stability. ${ }^{[5]}$ One of the most important issues to be considered here is the preservation of cerebral blood flow.

Cerebral blood flow (CBF) is one of the most important factors involved in maintaining brain metabolism. Cerebral blood flow is regulated by several different mechanisms (e.g., coupling, autoregulation). ${ }^{[6]}$ Cerebral autoregulation is the natural ability of the brain circulation to maintain constant cerebral blood flow during systemic blood pressure and cerebral perfusion pressure changes. ${ }^{[7]}$ Changes in systemic blood flow rate (SBFv) are thought to affect cerebral blood flow rate ( $C B F v)$. Thus, some of the changes in $\mathrm{CBFv}$ may be due to changes in $\mathrm{SBFv} .{ }^{[8]}$

Inhaled anesthetic agents have been shown to provide a dose-dependent increase in $\mathrm{CBF}^{[9]}$ In one study, it was stated that sevoflurane does not have a significant systemic hemodynamic effect in clinical application doses and does not affect static cerebral autoregulation and cerebrovascular reactivity. ${ }^{[10]}$ However, in another study, it was emphasized that regardless of the changes in SBFv, sevoflurane has an effect that directly reduces $\mathrm{CBFv}{ }^{[1 !]}$

In the light of all these data, we aimed to investigate the effects of steady-state sevoflurane anesthesia on hemodynamics and cerebral artery diameter measurements of patients undergoing FDD under general anesthesia.

\section{MATERIALS AND METHODS}

\section{Settings, Participants and Design}

This study was performed at our university hospital. After the approval of the ethics committee (2020/27/5) of the university hospital and written informed consent was obtained from enrolled patients. Forty-six patients aged 18-70 years undergoing FDD under general anesthesia were included.

Patients with mean arterial pressure (MAP) $<60 \mathrm{mmHg}$, inotropic agent administration, hemoglobin $<10$ and body tem- perature under 36C, head trauma, neurodegenerative disease, Glasgow Coma Scale (GCS) $=3$ were excluded from this study.

Initially, all patients underwent angiography computed tomography and the diagnosis was confirmed by digital subtraction angiography (DSA). All indications were determined by an interdisciplinary evaluation between neurosurgeons and interventional neuroradiologists.

General anesthesia was applied to all patients included in this study. Before the procedure, their GCS was evaluated and recorded. Routine monitoring was performed in the supine position. MAP, heart rate (HR), end-tidal $\mathrm{CO} 2$ (Et-CO2), peripheral oxygen saturation ( $\mathrm{SpO} 2)$, body temperature and Bispectral Index were continuously monitored. Blood pressure was measured non-invasively. Body temperature was measured orally in all patients.

Anesthesia induction was carried out with $\mathrm{I}-2 \mathrm{mg} / \mathrm{kg}$ propofol, $1.0 \mathrm{mcg} . \mathrm{kg}^{-1}$. min-I for I min, followed by $0.1 \mathrm{mcg} . \mathrm{kg}^{-1} \cdot \mathrm{min}-\mathrm{I}$ remifentanil and $0.6 \mathrm{mg} / \mathrm{kg}$ rocuronium. Continuous infusion of remifentanil continued after endotracheal intubation and controlled ventilation was established (Cato, Drager, Lubeck, Germany). Using an oxygen/air mixture with an $\mathrm{FiO}_{2}$ of 2, PEEP of $4 \mathrm{cmH}_{2} \mathrm{O}$, peak airway pressures were between 15 and 20 $\mathrm{cmH}_{2} \mathrm{O}$. Sevoflurane was used as the volatile agent in maintenance. The concentration of sevoflurane was titrated to a target Bispectral Index (BIS) between 40 and 60 (Covidien, Dublin, Ireland) and it was targeted at $<1$ MAC. Patients were kept normothermic (36-37 C) and normocapnic (end-tidal $\mathrm{CO}_{2}: 35-40 \mathrm{mmHg}$ ). It was planned to use $5 \mathrm{mg}$ ephedrine if $\mathrm{MAP}<60 \mathrm{mmHg}$ and $0.5 \mathrm{mg}$ atropine if $\mathrm{HR}<50 / \mathrm{min}$. Doses of the drugs used were recorded. Body temperature was maintained using body surface warming using a Bair Hugger.

Features of the aneurysm, antiplatelet drug use, demographic data, intensive care and hospital stay duration, complications and clinical results were recorded.

\section{Antiplatelet Treatment and Endovascular Procedure and Cerebral Artery Diameter Measurement}

Application of Tirofiban (Aggrastat, Merck, West Point, Pennsylvania, USA) to all patients was initiated before placing a flow diverter for 16/24 hours according to the manufacturer's guide, followed by oral double antiplatelet medication (for four consecutive months, aspirin $100 \mathrm{mg} /$ day and clopidogrel $75 \mathrm{mg} /$ day).

All procedures were performed under general anesthesia by an interventional neuroradiologist with at least 10 years of experience. Flow diverter selection and the number of implants used were planned at the operator's discretion and angiographic evaluation of each case. Technical success was defined as the successful deployment of the flow diverter. 
Aneurysm location (anterior circulation against posterior circulation) and size were recorded.

Internal carotid artery (ICA), middle cerebral artery (MCA) and anterior cerebral artery (ACA) diameter measurements were made from DSA images of patients with anterior aneurysms. Baseline artery (BA), right posterior cerebral artery (RPCA) and left posterior cerebral artery (LPCA) diameter measurements were made from DSA images of patients with posterior aneurysms. These measurements were recorded as preoperative measurements. The same measurements were made from the DSA images performed before the FDD placement procedure performed under steady-state sevoflurane anesthesia for the same patients. These measurements were recorded as peroperative measurements.

In all patients, DSA was provided with a single wall entry into the main femoral artery under the guidance of ultrasonography. 5F diagnostic catheter (Radifocus ${ }^{\circledR}$ Angiographic Catheter - Terumo) was used in the preoperative DSA and $5 \mathrm{~F}$ or $6 \mathrm{~F}$ guiding catheter (SOFIA ${ }^{\circledR}$ Microvention) was used in the operative DSA. Diagnostic angiographic images were obtained in the Town and lateral positions by giving $10-12 \mathrm{ml}$ of a non-ionic contrast agent (Ultravist 300, Schering, Berlin, Germany) at a rate of $5-6 \mathrm{ml} / \mathrm{sec}$ through an automatic injector. After the images to be measured preoperatively and peroperatively were determined, the Allura Xper FD 20/20 - DS angiography device workstations were calibrated according to the diagnostic or guide catheter diameter used. In the anterior system, diameters were measured from the ICA supraclinoid (C7) segment, from the middle sections of MCA $\mathrm{ml}$ and ACA al segments, and it was measured in the posterior system from the BA middle section, from the RPCA and LPCA PI segments.

\section{Statistical Analysis}

The results of our study were analyzed with the program "The Statistical Package for the Social Sciences 19.0 (SPSS Armonk, NY: IBM Corp.)". Data with continuous values were given as mean ( \pm standard deviation), categorical data were given as frequency and percentage $(n, \%)$. The data were tested for compatibility with normal distribution with the Kolmogorov-Smirnov test. Nonparametric data of the groups were compared using Mann - Whitney $U$ test and parametric data using the Independent t-test. Chi-square test was used to test categorical data. Pearson correlation test was used to determine the linear relationship between the variables. Logistic regression model was used to determine the independent risk factors affecting mortality. $\mathrm{P}<0.05$ value was considered significant.

\section{RESULTS}

The mean age of the patients included in this study was $56.6 \pm 15.1$ (18-70), and 25 (54.3\%) of them were male. GCS before the procedure was $13.2 \pm 3.4$ (4-15). The aneurysm diameter of the patients was $8.7 \pm 4.0(4-25) \mathrm{mm}$. The duration of intensive care and hospital stay of the patients was $5.4 \pm 12$.I (0-56) days, and I0.5 I I $.7(2-56)$ days, respectively, and $45.7 \%$ of the patients did not need intensive care. Demographic data, anesthetic agent consumption and hemodynamic data of the patients are presented in Table I.

The MAP value of the patients before the induction was $76.28 \pm 5.13 \mathrm{mmHg}$, the MAP value after the induction was $64.36 \pm 3.23 \mathrm{mmHg}$, and the MAP value during sevoflurane anesthesia was $68.26 \pm 4.30 \mathrm{mmHg}$. The relationship between MAP values before and after induction, during induction and sevoflurane anesthesia, is presented in Figure I.

Table I. Other system and organ injuries

\begin{tabular}{|c|c|c|}
\hline & $\begin{array}{c}\text { Mean } \pm S D \\
(n=46)\end{array}$ & $\begin{array}{c}\operatorname{Min}-\operatorname{Max} \\
(n=46)\end{array}$ \\
\hline Age (year) & $56.6 \pm 15.1$ & $18-70$ \\
\hline Weight (kg) & $71.06 \pm 8.95$ & $55-90$ \\
\hline Propofol (mg) & $106.5 \pm 13.42$ & $82.5-135$ \\
\hline Sevoflurane (ml) & $13.70 \pm 2.82$ & $8.70-19.57$ \\
\hline $\mathrm{EtCO}_{2}$ & $37.65 \pm 1.84$ & $35-40$ \\
\hline Temperature $\left({ }^{\circ} \mathrm{C}\right)$ & $36.43 \pm 0.27$ & $36-36.9$ \\
\hline $\mathrm{SpO}_{2}(\%)$ & $97.39 \pm 1.02$ & $96-99$ \\
\hline Heart Rate (/dk) & $67.52 \pm 6.14$ & $55-80$ \\
\hline GCS & $13.2 \pm 3.4$ & $4-15$ \\
\hline Diameter (mm) & $8.7 \pm 4.0$ & $4-25$ \\
\hline ICU Time (day) & $5.4 \pm 12.1$ & $0-56$ \\
\hline Hospital Time (day) & $10.5 \pm 11.7$ & $2-56$ \\
\hline
\end{tabular}

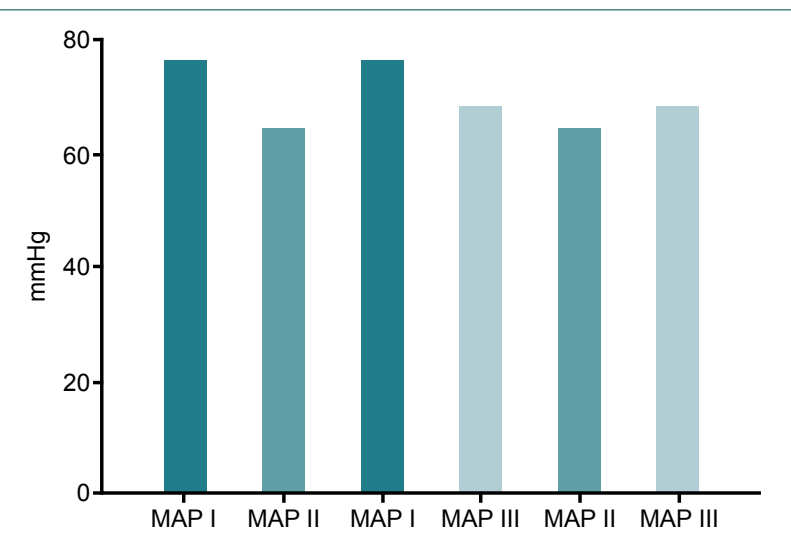

Figure 1. Comparison of MAP values before and after induction and during sevoflurane anesthesia of patients. ${ }^{* * *} / * * *: p<0.001$, MAP I; mean arterial pressure before induction, MAP II; mean arterial pressure after induction, MAP III; mean arterial pressure during sevoflurane anesthesia. 

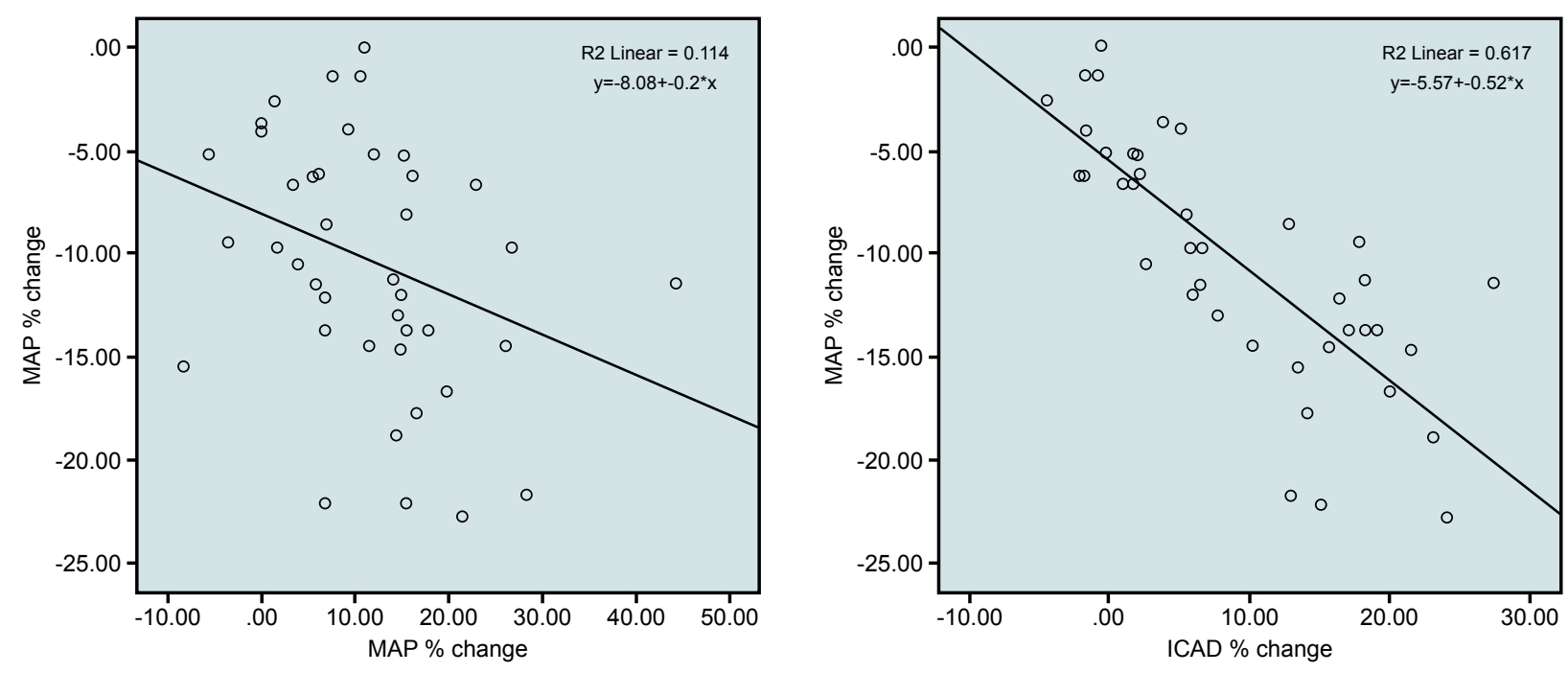

Figure 2. Correlation between MAP \% change with MCA and ICA diameter change $\%$.

The aneurysm localization of the patients is presented in Table 2 .

Table 2. Aneurysm localization of patients

\begin{tabular}{lcc}
\hline Diagnosis (Aneurysm) & n & $\%$ \\
\hline Left middle cerebral artery & 4 & 8.7 \\
Right internal carotid artery & 10 & 21.7 \\
Left anterior cerebral artery & 4 & 8.7 \\
Right middle cerebral artery & 9 & 19.6 \\
Right posterior cerebral artery & $\mathrm{I}$ & 2.2 \\
Left internal carotid artery & 2 & 4.3 \\
Right anterior inferior cerebral artery & $\mathrm{I}$ & 2.2 \\
Right vertebral artery & $\mathrm{I}$ & 2.2 \\
Basillary artery & 3 & 6.5 \\
Right anterior cerebral artery & $\mathrm{I}$ & 2.2 \\
Anterior communican artery (aca) & 9 & 19.6 \\
Posterior internal carotid artery & $\mathrm{I}$ & 2.2 \\
\hline
\end{tabular}

There was a statistically significant difference between the preoperative and peroperative values of cerebral artery diameters measured from three different locations in patients with anterior cerebral artery aneurysm $(p<0.001)$. A statistically significant difference was observed between the preoperative and peroperative measurements of LPCA diameters of patients with posterior cerebral artery aneurysm $(p=0.005)$ (Table 3).

In Pearson correlation analysis, there was a strong relationship between the percentage of MAP change and the percentage of ICA diameter change $(p<0.001, p=-0.785)$ and $a$ moderate relationship with the percentage of MCA diameter change $(p=0.033, p=-0.338)$ ( $P$ : Pearson's Rho Correlation Coefficient) (Fig. 2).

No complications developed in any patient during the procedure. Mortality developed in six patients (13.04\%).

To determine the independent risk factors that affect the development of mortality, logistic regression analysis, including age, sex, GCS, duration of operation, aneurysm diameter,

Table 3. Comparison of patients' preoperative and peroperative cerebral artery diameters

\begin{tabular}{|c|c|c|c|c|c|}
\hline & (n) & Preoperative & Peroperative & $\begin{array}{c}\text { 95\% Confidence Interval } \\
\text { Lower/Upper }\end{array}$ & p-value \\
\hline Internal carotid artery & 40 & $3.34 \pm 0.56$ & $3.62 \pm 0.52$ & $-0.36 /-0.19$ & $<0.001$ \\
\hline Middle cerebral artery & 40 & $2.43 \pm 0.34$ & $2.69 \pm 0.30$ & $-0.33 /-0.18$ & $<0.001$ \\
\hline Anterior cerebral artery & 40 & $1.94 \pm 0.38$ & $2.09 \pm 0.38$ & $-0.23 /-0.07$ & $<0.001$ \\
\hline Basillary artery & 6 & $3.49 \pm 0.78$ & $3.80 \pm 1.02$ & $-0.62 / 0.00$ & 0.052 \\
\hline Right posterior cerebral artery & 6 & $1.86 \pm 0.36$ & $1.93 \pm 0.42$ & $-0.26 /-0.12$ & 0.408 \\
\hline Left posterior cerebral artery & 6 & $2.02 \pm 0.40$ & $2.19 \pm 0.33$ & $-0.27 /-0.07$ & 0.005 \\
\hline
\end{tabular}


MAP change percentage and change percentages of cerebral artery diameters, was performed. Low GCS scores (OR: I.658, $\mathrm{p}=0.037,95 \% \mathrm{Cl}$ : I.030-2.668) were determined as independent risk factors affecting mortality development.

\section{DISCUSSION}

Most neurointerventional procedures are performed under general anesthesia as it provides greater patient safety and better image quality due to patient immobilization. ${ }^{[5]}$

We also preferred general anesthesia in our patients to standardize conditions that may have cerebral vasodilator effects. Anesthesia induction was achieved with propofol and remifentanil, and sevoflurane was added as a volatile agent to remifentanil during maintenance. Anesthesia depth was monitored with BIS $(40<\mathrm{BIS}<60)$, and $<$ I MAC sevoflurane was applied to the patients.

In normal intracranial pressure (normal neurological examination) ruptured or unruptured aneurysm, a maximum of 140 $\mathrm{mmHg}$ should be targeted so that the patient has normal systolic blood pressure. MAP should be targeted to be $\geq 60$ mmHg. ${ }^{[2]}$ It has been shown that I MAC sevoflurane, which is often used, does not have systemic hemodynamic effects. ${ }^{[13]}$ In a study in which propofol fentanyl was used for the induction of anesthesia and sevoflurane for maintenance, MAP decreased in the induction phase, while aortic and pulse pressure increased. In the later phases, there was no significant change in hemodynamic parameters, and it was emphasized that sevoflurane had no systemic effect. Peripheral vasodilation in this induction phase has been linked to propofol use. ${ }^{[10]}$

Similar to the aforementioned study, in our patient group, there was a significant decrease in MAP after induction compared to baseline values. This significant decrease was also observed during sevoflurane anesthesia. Although this decrease was more pronounced in the induction phase, none of the patients had MAP values below $60 \mathrm{mmHg}$, and no inotropic agent was used. <I MAC sevoflurane anesthesia was significant in patients undergoing FDD procedure according to the baseline value, and the systemic effect of sevoflurane was significant.

In the traditional concept of cerebral autoregulation, the steady-state CBF remains relatively stable despite large changes in arterial blood pressure. ${ }^{[14]} \mathrm{CBF}$ reacts quickly to temporary changes in arterial blood pressure. ${ }^{[15]}$ The cerebral vascular bed buffers these changes in CBF caused by temporary changes in arterial blood pressure. Changes in perfusion pressure produce marked changes in cerebrovascular resistance, thus preserving CBF relatively. ${ }^{[10]}$

Inhalation anesthetics are cerebral vasodilators. While reducing cerebral metabolic rate (CMR), they can blunt cerebral autoregulation by separating $\mathrm{CBF}$ and metabolism, thereby increasing CBF and intracranial pressure. ${ }^{[16,17]}$ In $<$ I MAC values, the net effect is a modest decrease in CBF, and generally, $\mathrm{CO} 2$ responsiveness is maintained. However, $\mathrm{CBF}$ increases more noticeably at $>$ I MAC concentrations. ${ }^{[18,19]}$ Inhalation anesthetic agents have been shown to provide a dose-dependent increase in CBF. The magnitude of this increase is dependent on the balance between the agent's intrinsic vasodilatory action and the vasoconstriction secondary to flowmetabolism coupling. ${ }^{[9]}$ Previous studies have indicated that sevoflurane between 0.5-1.0 MAC has a minimal direct vasodilator effect on brain arterioles. ${ }^{[20,21]}$

In our study, peroperative cerebral artery diameters were significantly higher than preoperative diameters. The reason why this significance was low in posterior cerebral artery diameters was attributed to the low number of cases in the measurement of posterior cerebral artery diameters. The change percentages of cerebral artery diameters measured from ICA and MCA were correlated with the change percentages in MAP. However, it was observed that cerebral artery diameter change percentages and MAP change percentages had no role in the development of mortality.

In most of the studies performed so far, CBFv was evaluated using MCA in this evaluation. It was emphasized that CBFv, as measured from MCA, is not a direct CBF measurement. However, it has also been shown that changes in $C B F v$ are reliably correlated with changes in $\mathrm{CBF}$ in the presence of fixed vessel diameter. ${ }^{[22-26]}$

One advantage of our study is that the cerebral artery diameters of our patients were directly visualized by DSA and the cerebral artery diameters under baseline and anesthesia were compared. In our study, ICA and ACA diameters were evaluated besides MCA, where CBF was commonly evaluated in the literature. The increase in the cerebral artery diameters compared to baseline showed significance in all three regions. Our study has some limitations. One of the limitations was that different MAC values of sevoflurane were not compared. However, in the literature, although it was stated that sevoflurane was a minimal vasodilator between $0.5-I$ MAC values, it was observed in our study that the vasodilatory effect of <I MAC sevoflurane in cerebral arteries was significant, and it is likely this significance would be observed in $>$ I MAC sevoflurane.

The second limitation of this study was that only cerebral artery diameters were evaluated, and simultaneous CBF was not evaluated. However, it was stated that CBFv measured by Doppler is not a direct measure of CBF, but CBFv correlates to CBF only in the presence of fixed cerebral artery diameter. In conclusion, in patients undergoing FDD procedure under sevoflurane anesthesia, <I MAC sevoflurane has a hemodynamic effect and creates significant vasodilation in the cerebral artery diameters. There is a significant correlation between cerebral artery diameter changes (ICA-MCA) and 
MAP changes, but these variables have no effect on mortality. Prospective randomized studies are needed to support all these data in the future.

Ethics Committee Approval: Approved by the local ethics committee.

Peer-review: Internally peer-reviewed.

Authorship Contributions: Concept: Ş.A., S.B.; Design: Ş.A., S.B., O.K., R.Y.; Supervision: A.T., STU; Resource: Ş.A., S.B., G.H.; Materials: Ş.A., S.B., R.Y., O.K.; Data: Ş.A., S.B., O.K.; Analysis: Ş.A., R.Y., A.T., S.T.U; Literature search: Ş.A., G.H., R.Y.; Writing: Ş.A., S.B., A.T.; Critical revision: O.K., A.T., S.T.U.

\section{Conflict of Interest: None declared.}

Financial Disclosure: The authors declared that this study has received no financial support.

\section{REFERENCES}

1. Austin GM, Schievink W, Williams R. Controlled pressure-volume factors in the enlargement of intracranial aneurysms. Neurosurgery 1989;24:722-30. [CrossRef]

2. Briganti F, Leone G, Marseglia M, Mariniello G, Caranci F, Brunetti A, et al. Endovascular treatment of cerebral aneurysms using flow-diverter devices: A systematic review. Neuroradiol J 2015;28:365-75. [CrossRef]

3. Griessenauer CJ, Shallwani H, Adeeb N, Gupta R, Rangel-Castilla L, Siddiqui AH, et al. Conscious Sedation Versus General Anesthesia for the Treatment of Cerebral Aneurysms with Flow Diversion: A Matched Cohort Study. World Neurosurg 2017;102:1-5. [CrossRef]

4. Chamczuk AJ, Ogilvy CS, Snyder KV, Ohta H, Siddiqui AH, Hopkins $\mathrm{LN}$, et al. Elective stenting for intracranial stenosis under conscious sedation. Neurosurgery 2010;67:1189-93; discussion 1194. [CrossRef]

5. Joung KW, Yang KH, Shin WJ, Song MH, Ham K, Jung SC, et al. Anesthetic consideration for neurointerventional procedures. Neurointervention 2014;9:72-7. [CrossRef]

6. Werner CKE, Hoffmann WE. Cerebral blood flow and metabolism. In: Albin MS, editor. Textbook of Neuroanesthesia with Neurosurgical and Neuroscience Perspectives. New York: McGraw-Hill; 1997.p.21-59.

7. Settakis G, Molnár C, Kerényi L, Kollár J, Legemate D, Csiba L, et al. Acetazolamide as a vasodilatory stimulus in cerebrovascular diseases and in conditions affecting the cerebral vasculature. Eur J Neurol 2003;10:609-20. [CrossRef]

8. Lindegaard KF, Nornes H, Bakke SJ, Sorteberg W, Nakstad P. Cerebral vasospasm diagnosis by means of angiography and blood velocity measurements. Acta Neurochir (Wien) 1989;100:12-24. [CrossRef]

9. Hansen TD, Warner DS, Todd MM, Vust LJ. The role of cerebral metabolism in determining the local cerebral blood flow effects of volatile anesthetics: evidence for persistent flow-metabolism coupling. J Cereb Blood Flow Metab 1989;9:323-8. [CrossRef]

10. Juhász M, Molnár L, Fülesdi B, Végh T, Páll D, Molnár C. Effect of sevoflurane on systemic and cerebral circulation, cerebral autoregulation and $\mathrm{CO} 2$ reactivity. BMC Anesthesiol 2019;19:109. [CrossRef]

11. Holzer A, Greher M, Hetz H, Standhardt H, Donner A, Heinzl H, et al. Influence of aortic blood flow velocity on changes of middle cerebral artery blood flow velocity during isoflurane and sevoflurane anaesthesia. Eur J Anaesthesiol 2001;18:238-44. [CrossRef]

12. Diringer MN, Bleck TP, Claude Hemphill J 3rd, Menon D, Shutter L, Vespa P, Bruder N, et al; Neurocritical Care Society. Critical care management of patients following aneurysmal subarachnoid hemorrhage: recommendations from the Neurocritical Care Society's Multidisciplinary Consensus Conference. Neurocrit Care 2011;15:211-40. [CrossRef]

13. Ebert TJ, Harkin CP, Muzi M. Cardiovascular responses to sevoflurane: a review. Anesth Analg 1995;81:S11-22. [CrossRef]

14. Paulson OB, Strandgaard S, Edvinsson L. Cerebral autoregulation. Cerebrovasc Brain Metab Rev 1990;2:161-92.

15. Busija DW, Heistad DD, Marcus ML. Effects of sympathetic nerves on cerebral vessels during acute, moderate increases in arterial pressure in dogs and cats. Circ Res 1980;46:696-702. [CrossRef]

16. Todd MM, Drummond JC. A comparison of the cerebrovascular and metabolic effects of halothane and isoflurane in the cat. Anesthesiology 1984;60:276-82. [CrossRef]

17. Lutz LJ, Milde JH, Milde LN. The cerebral functional, metabolic, and hemodynamic effects of desflurane in dogs. Anesthesiology 1990;73:125-31. [CrossRef]

18. Mielck F, Stephan H, Weyland A, Sonntag H. Effects of one minimum alveolar anesthetic concentration sevoflurane on cerebral metabolism, blood flow, and $\mathrm{CO} 2$ reactivity in cardiac patients. Anesth Analg 1999;89:364-9. [CrossRef]

19. Ornstein E, Young WL, Fleischer LH, Ostapkovich N. Desflurane and isoflurane have similar effects on cerebral blood flow in patients with intracranial mass lesions. Anesthesiology 1993;79:498-502. [CrossRef]

20. Kadoi Y, Takahashi K, Saito S, Goto F. The comparative effects of sevoflurane versus isoflurane on cerebrovascular carbon dioxide reactivity in patients with diabetes mellitus. Anesth Analg 2006;103:168-72. [CrossRef]

21. Matta BF, Heath KJ, Tipping K, Summors AC. Direct cerebral vasodilatory effects of sevoflurane and isoflurane. Anesthesiology 1999;91:677-80.

22. Bishop CC, Powell S, Rutt D, Browse NL. Transcranial Doppler measurement of middle cerebral artery blood flow velocity: a validation study. Stroke 1986;17:913-5. [CrossRef]

23. Kirkham FJ, Padayachee TS, Parsons S, Seargeant LS, House FR, Gosling RG. Transcranial measurement of blood velocities in the basal cerebral arteries using pulsed Doppler ultrasound: velocity as an index of flow. Ultrasound Med Biol 1986;12:15-21. [CrossRef]

24. Kochs E, Hoffman WE, Werner C, Albrecht RF, Schulte am Esch J. Cerebral blood flow velocity in relation to cerebral blood flow, cerebral metabolic rate for oxygen, and electroencephalogram analysis during isoflurane anesthesia in dogs. Anesth Analg 1993;76:1222-6. [CrossRef]

25. Aaslid R. Transcranial Doppler examination techniques. In: Aaslid R, editor. Transcranial Doppler Sonography. New York: Springer; 1986.p.39-56. [CrossRef]

26. Eng C, Lam AM, Mayberg TS, Lee C, Mathisen T. The influence of propofol with and without nitrous oxide on cerebral blood flow velocity and CO2 reactivity in humans. Anesthesiology 1992;77:872-9. [CrossRef] 


\section{ORİIINAL ÇALIŞMA - ÖZET}

\section{Intrakraniyal anevrizmanın endovasküler tedavisinde sevofluran anestezisinin hemodinamik ve serebral arter çaplarına etkisi: Pilot çalışma \\ Dr. Şule Arıcan, ${ }^{1}$ Dr. Süleyman Bakdık, ${ }^{2}$ Dr. Gülçin Hacıbeyoğlu, ${ }^{1}$ Dr. Resul Yilmaz, ${ }^{1}$ Dr. Osman Koç, ${ }^{2}$ Dr. Aybars Tavlan, ${ }^{1}$ Dr. Sema Tuncer Uzun ${ }^{1}$}

${ }^{1}$ Necmettin Erbakan Üniversitesi Tıp Fakültesi, Anesteziyoloji ve Reanimasyon Anabilim Dalı, Konya ${ }^{2}$ Necmettin Erbakan Üniversitesi Tıp Fakültesi, Radyoloji Anabilim Dalı, Konya

AMAÇ: Serebral otoregülasyon, arteriyel kan basıncındaki büyük değişikliklere rağmen kararlı durum serebral kan akımının sabit kalmasıdır. İnhalasyon anestezikleri serebral vazodilatörlerdir. <। MAC değerlerinde, net etki serebral kan akımında ıımlı bir azalma ve karbondioksite yanıt verebilirliğin korunmasıdır. Bu çalışmanın amacı, genel anestezi altında akış saptııııı cihaz yerleşimi uygulanan hastalarda kararlı durum sevofluran anestezisinin hemodinamik ve serebral arter çap ölçümleri üzerindeki etkisini araştırmaktır.

GEREÇ VE YÖNTEM: Genel anestezi altında akış saptırıcı cihaz yerleşimi yapılan 18-70 yaş arası 46 hasta dahil edildi. Hastalara rutin monitorizasyon yapıldı. Ortalama arter basınç (OAB) değerleri kaydedildi. Anterior yerleşimli anevrizması olan hastaların Dijital Subtraksiyon Anjiyografı (DSA) görüntülerinden internal karotis arter, orta serebral arter ve anterior serebral arter çap ölçümleri yapıldı. Posterior yerleşimli anevrizması olan hastaların DSA görüntülerinden baziller arter, sağ posteriyor serebral arter ve sol posteriyor serebral arter çap ölçümleri yapıldı. Bu ölçümler ameliyat öncesi ölçümler olarak kayıt edildi. Aynı hastaların kararlı durum sevofluran anestezisi alında gerçekleştirilen akış saptırıcı cihaz yerleştirme işlemi öncesinde yapılan DSA görüntülerinden aynı ölçümler gerçekleştirildi. Bu ölçümler ameliyat sırasında ölçümler olarak kayıt edildi.

BULGULAR: Hastaların yaş ortalaması $56.6 \pm 15$. I'idi. Hastaların indüksiyon öncesi $O A B ; 76.28 \pm 5.13 \mathrm{mmHg}$, indüksiyon sonrası $O A B ; 64.36 \pm 3.23$ $\mathrm{mmHg}$ ve sevoflurane anestezisi sırasında $O A B ; 68.26 \pm 4.30 \mathrm{mmHg}$ idi ve istatistiksel olarak anlamlı farklılık vardı. Anteriyor serebral arter çaplarının ameliyat öncesi ve ameliyattaki değerleri arasında istatistiksel olarak anlamlı farklıık gözlendi. OAB değişim yüzdesi ile internal karotis arter çap değişim yüzdesi arasında $(p<0.00$ I, $p=-0.785)$ kuvvetli, orta serebral arter çap değişim yüzdesi arasında $(p=0.033, p=-0.338)$ orta düzeyde bir ilişki mevcuttu.

TARTIŞMA: Akış saptırıcı cihaz yerleşimi uygulanan hastalarda, <I MAC sevofluranin hemodinamik etkisi vardır ve serebral arter çaplarında anlamlı olarak vazodilatasyon yapmaktadır.

Anahtar sözcükler: Akış saptıııı cihaz; genel anestezi; serebral arter çapı; sevofluran.

Ulus Travma Acil Cerrahi Derg 2021;27(2):200-206 doi: 10.14744/tjtes.2021.00269 